Waste and Resource Management Volume 167 Issue WR4

Resource efficiency networks in the construction of new buildings

Williams, Curran, den Boer et al.
Proceedings of the Institution of Civil Engineers

Waste and Resource Management 167 November 2014 Issue WR4

Pages 139-152 http://dx.doi.org/10.1680/warm.13.00030

Paper 1300030

Received 19/09/2013 Accepted 13/05/2014

Keywords: recycling \& reuse of materials/waste management \&

disposal

\title{
Resource efficiency networks in the construction of new buildings
}

Ian D. Williams

Professor of Applied Environmental Science, Centre for Environmental Sciences, Faculty of Engineering and the Environment, University of

Southampton, Southampton, UK

Tony Curran

Research Fellow, Centre for Environmental Sciences, Faculty of Engineering and the Environment, University of Southampton, Southampton, UK

Emilia den Boer

Dr-Ing, Assistant Professor, Wrocław University of Technology, Institute of Environment Protection Engineering, Wroclaw, Poland

\author{
Andreas Pertl \\ Researcher, Institute of Waste Management, BOKU-University of Natural \\ Resources and Life Sciences, Vienna, Austria \\ Diana Lock \\ Chief Executive, Remade SouthEast, Rochester, UK \\ Andrew Kent \\ Researcher, Remade SouthEast, Rochester, UK \\ Phil Wilding \\ Chief Executive, Wilding Butler Construction Ltd, Winchester, UK
}

This paper reports on a study to develop a construction resource efficiency stakeholder network in the UK. The primary stakeholders in the network were the client, designer and main contractor - the decision-makers on construction techniques, materials and products. The paper outlines the rationale for the study, development of waste-prevention measures and industrial networks, progressive implementation in three separate construction activities, barriers and practical constraints, key results, conclusions and recommendations. Improvements were achieved through increased specification and use of sustainably produced construction materials, greater separation of materials for recycling, increased reuse of materials and behaviour changes in energy and water use as a result of on-site monitoring.

\section{Introduction}

The construction sector specialises in the design and building of homes, schools, offices, hospitals and infrastructure and is hugely important to the European economy. As an example, in 2009 , the construction sector contributed $7 \cdot 8 \%$ to the UK's gross domestic product, with over one million companies employing $2 \cdot 18$ million people, or $9 \cdot 6 \%$ of total employment in the UK (SFC, 2011).

Although the prevailing economic climate has affected the size and output of the construction industry, it remains one of the most environmentally significant sectors. The industry consumes $380 \mathrm{Mt}$ of material each year and is one of the largest waste-producing sectors, generating $77 \mathrm{Mt}$ of construction, demolition and excavation waste per year (England only) (Hobbs, 2008). This equates to around 33\% of all waste generated in the UK. As much as $80 \%$ of UK construction and demolition waste is reusable or recyclable (Ferguson et al., 1995), although only $52 \%$ of such materials are currently recycled (Defra, 2009). The construction, demolition and excavation wastes landfilled in 2009 were characterised as: soils and stone $(46 \%)$; waste from transfer stations, including mixed waste $(39 \%)$; concrete, bricks, tiles and ceramics $(6 \%)$; dredging spoil ( $3 \%)$; construction materials containing asbestos $(2 \%)$; hazardous stones and rock $(1 \cdot 5 \%)$; inert rock and stone $(1 \cdot 5 \%)$; wood, glass and plastic $(0 \cdot 5 \%)$; metal, insulation, bituminous products and gypsum $(0 \cdot 5 \%)$ (SFC, 2011). Clearly, there is considerable potential within the construction industry to improve waste management practices, although there are significant barriers to overcome, including a deep-rooted wasteful culture and a widespread perception that sustainable waste management is expensive (Williams and Turner, 2011).

Environmental schemes have typically met resistance in the construction sector, mainly because of entrenched business practices, neglect and/or the perception that environmental considerations are expensive and time-consuming. Wellintentioned initiatives such as the European Pathway to Zero Waste (see www.environment-agency.gov.uk/aboutus/ wfo/epow), the Strategic Forum for Construction (see www. strategicforum.org.uk), the National Industrial Symbiosis Programme (see www.nispnetwork.com) and the Zero Waste Institute (see http://zerowasteinstitute.org), have only had marginal impacts to date. Some initiatives have totally failed: the site waste management plans (SWMP) regulations came into force in the UK in April 2008 with the aim of forcing construction companies undertaking projects over $£ 300000$ to produce a detailed plan explaining how waste will be minimised, reused, recycled and safely disposed of. The intention was to encourage good practice waste minimisation and management that generates environmental and financial savings. However, because of the industry's poor performance, the UK government removed SWMP regulations from the statute in 2013 . 
Waste and Resource Management

Volume 167 Issue WR4
Resource efficiency networks in

the construction of new

buildings

Williams, Curran, den Boer et al.
The construction sector continues to be seen as conservative, risk averse and reluctant to adopt new technologies and ideas, resorting to tried and tested methods of construction rather than using innovative technologies and practices. That said, the sheer size and throughput - over 40000 in 2014 (UBM, 2014) - of the annual Ecobuild conference in London is one indication that many actors in the industry are leading on or embracing more sustainable construction practices and products. Examples of best practice do exist in the UK but are rare, for example Plummerswood and the Glencoe visitor centre in Scotland were constructed with low energy and resource use, design-for-deconstruction and reuse principles in mind (Passivhaus Trust, 2012; SC-Arch, 2002; WRAP, 2014). A performance assessment of the Portuguese construction industry concluded that small, specialised companies and large contractors tend to achieve the best performance levels, and this may be linked to innovativeness (Horta et al., 2012). This supports a view that typical (non-specialist) small and mediumsized enterprises, which make up the majority of the construction industry, may struggle to drive innovative practices.

Environmental initiatives that could have a significant impact on the construction sector include the following.

Closing the resource loop: replacing raw materials with recycled and/or reused elements.

- The specification and use of sustainable products and materials: designating that a project uses products made from waste or sustainable source materials reduces the consumption of primary resources. The assessment and specification of sustainable materials and products is complex but organisations such as the UK's Building Research Establishment (BRE), the Construction Products Association and the Waste Resources Action Programme (WRAP) provide guidance to construction companies.

- Water savings: activities such as dust suppression and wheel washing that use high volumes of water can be made more sustainable by supplementing or replacing fresh water with waste or grey water deemed suitable for this purpose. Technologies and practices that reduce water use include off-site construction and replacement of materials that require wet trades (such as plastering and concreting) on site. The UK construction sector alone may use $\sim 150 \mathrm{~m}^{3}$ of water per £1 million contractors' output; it was estimated by the Strategic Forum for Construction that in 2008 the construction and demolition sectors used 14 million $\mathrm{m}^{3}$ of fresh water (e.g. on construction sites, SFC, 2011).

- Carbon savings: activities like reducing vehicle movements, using fuel-efficient plant and machinery, metering electricity use, undertaking good practice energy management and energy-efficient site accommodation can be implemented to reduce the carbon dioxide footprint of projects. Technologies and practices that reduce energy use include off-site construction and replacement or substitution of energy-intensive materials. Tough targets have been set by the EU, UK and local government to reduce carbon dioxide emissions; the construction sector contributes $\sim 7 \%$ of the overall greenhouse gas emissions for the UK each year.

Accreditation schemes: the code for sustainable homes and the BRE's environmental assessment methodology provide credits for implementing programmes that meet specified minimisation, reuse and recycling targets. These schemes have tended to target social housing and commercial developments and are driven by the clients and their approach to sustainable development.

- Training and education: for example, providing 'toolbox talks' on site to staff and subcontractors to highlight 'quick wins' in terms of minimising energy and water use and waste arisings.

Financial drivers have had some success. The landfill tax is a levy on the disposal of waste and it applies to all waste disposed of at landfills. It was introduced to encourage waste producers to generate less waste and recover more value from waste. Since the introduction of the landfill tax in the UK, the standard amount of tax payable on each tonne of waste sent to landfill has increased from $£ 7$ in 1996/1997 to $£ 72$ in 2013/2014. However, a low rate of $£ 2 \cdot 50 / \mathrm{t}$ is charged on 'inactive' waste. Inactive waste covers most materials used in a building's fabric - most forms of concrete, brick, glass, soil, clay and gravel - as well as earth excavated for foundations. Nevertheless, the tax has influenced the industry to identify new and innovative ways to reuse and recycle waste materials. Legislative drivers such as the revised waste framework directive require that all member states recover a minimum of $70 \%$ of the waste generated from the construction and demolition industry by 2020.

This applied case study review paper addresses one part of the 'Towards zero waste in industrial networks (Zerowin)' project (see www.zerowin.eu), which ran from mid-2009 to April 2014. The project created innovative technologies, waste-prevention methodologies, strategies and system tools based on the vision reported by Curran and Williams (2012). This included a broad review of the literature in this field (Williams and Curran, 2010). A set of practical demonstrators formed the core of the project; five of which were in the construction and demolition sector. The aim of this Zerowin case study was to develop a construction resource efficiency stakeholder network in the UK. The primary stakeholders in the network for each project were the client, designer and main contractor - the decision-making actors that affect the construction techniques, materials and products to be used. The stakeholder networks created an industrial network of suppliers and disposal options that reduced consumption of resources - construction and demolition 
subcontractors, waste management and recycling companies, material and product suppliers.

The sites evaluated in this paper were one-off pilot applications, so longer-term network development was limited, but this would be expected to occur naturally. This would stem from development of trust between actors, from previous mutually beneficial experiences, and would be enhanced by the leadership of forward-thinking, innovative stakeholders.

This paper outlines the rationale for the study; the development of waste prevention measures and industrial networks; progressive implementation in three separate construction activities; barriers and practical constraints; key results; conclusions and recommendations.

\section{Methods}

\subsection{Site selection}

Construction projects tend to be bespoke with building use, type, size, duration of construction, materials and construction methods driven by the commissioning client. This means that no two construction projects are identical, with input and output materials changing, along with suppliers, manufacturers and subcontractors. To enable a consistent industrial network to be created, a common set of criteria was developed to make sure that the three selected projects had similar methods and materials, which would facilitate the effective progression and development of the industrial network. The criteria were that the project had to be

located within a $50 \mathrm{~km}$ radius of the contractor's head office

built using similar construction methods and input materials

concrete pad and strip foundations

reinforced concrete frame, in situ slabs and roof brickwork/cladding external leaf

metal stud partitions internally, insulated and plaster-boarded

- elements that could be manufactured off site

carpentry and joinery works.

- able to measure water and electricity use on site by metering.

A progression pattern for each site/project was necessary so that an industrial network could be created and developed, as follows.

Phase 1 (site 1): build only (map the existing supply chain actors).

- Phase 2 (site 2): build only with some material influence (improvement 1).

Phase 3 (site 3): design and build (improvement 2).

It was decided that including three projects in the case study would allow sufficient opportunity to implement the desired Zerowin approaches, and include iterative improvements over the course of the research project.

\subsection{Construction works and sequencing}

The three construction projects conducted by Wilding Butler were selected for inclusion in the case study as they met the criteria listed and were due to be completed within the Zerowin project timeframe. These are summarised in Tables 1, 2 and 3, respectively. Wilding Butler is a medium-sized construction contractor, based near Winchester, Hampshire. Data from phase 1 were collected to establish baseline data. The sites in phases 2 and 3 focused on implementing improvements to reduce resource use in the construction process and maximise recovery by working with different actors in the industrial network. Unlike the phase 1 and 2 sites, the phase 3 design and build project enabled Wilding Butler to influence material selection and construction processes. The development of a sound business and environmental case helped win agreement

\begin{tabular}{ll}
\hline Location & Aldershot, Hampshire, UK \\
Classification & Mixed-use development - four floors \\
Client & Housing association (step by step) \\
Project type & Demolition and new build \\
Construction type & Concrete frame \\
Cost & $\mathrm{f} 2 \cdot 3$ million \\
Floor area: $\mathrm{m}^{2}$ & 1395 \\
Total site area: $\mathrm{m}^{2}$ & 350 \\
Project duration & March 2010 to June 2011
\end{tabular}

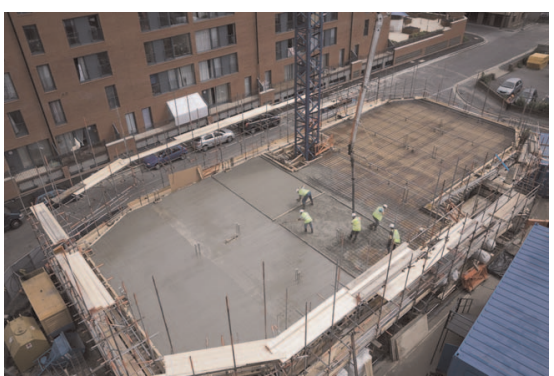

Table 1. Phase 1 (baseline): step by step, Aldershot, Hampshire, UK: site details 
Waste and Resource Management

Volume 167 Issue WR4
Resource efficiency networks in

the construction of new

buildings

Williams, Curran, den Boer et al.

$\begin{array}{ll}\text { Location } & \text { Reading, Berkshire, UK } \\ \text { Classification } & \text { Education - one floor } \\ \text { Client } & \text { Reading School and the Education Trust } \\ \text { Project type } & \text { Demolition and new build } \\ \text { Construction type } & \text { Load-bearing masonry } \\ \text { Cost } & £ 1 \cdot 2 \text { million } \\ \text { Floor area: } \mathrm{m}^{2} & 450 \\ \text { Total site area: } \mathrm{m}^{2} & 580 \\ \text { Project duration } & \text { July } 2011 \text { to April } 2012\end{array}$

Location

Classification

Project type

Construction type

Cost

Total site area:
Project duration

July 2011 to April 2012

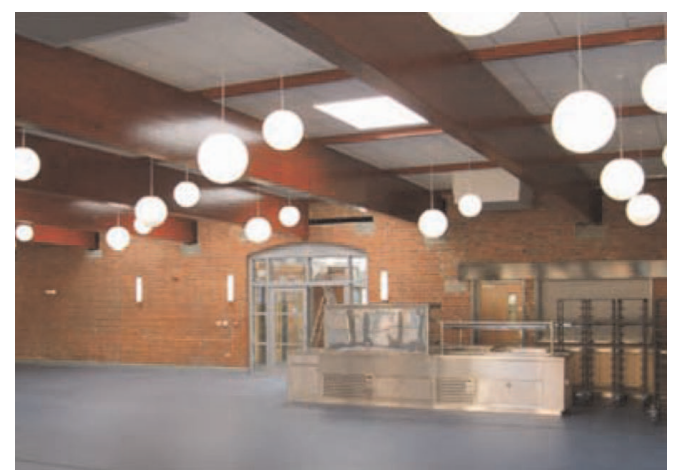

Table 2. Phase 2 (improvement 1): Reading School, Reading,

Berkshire, UK: site details

of the client to specify materials with reduced resource use and carbon dioxide intensity/emissions.

\subsection{Selection of materials and development of industrial networks}

The industrial network was developed iteratively and was influenced by the knowledge/experience of consortium members, the ability of prospective suppliers to meet the project specifications for each phase, and the potential of materials and activities that could be implemented on site to meet the Zerowin targets. Materials and potential activities were initially classified within the respective targets, as outlined below.

\subsubsection{Reducing greenhouse gas emissions by $30 \%$}

materials with lower embodied carbon dioxide and water

materials that facilitate the reduction of energy use on site

reduction of distances travelled by suppliers and subcontractors to deliver products and services to site; procuring locally and backfilling loads where possible use of on-site accommodation that incorporates energysaving devices

niring machinery that can use biodiesel.

\subsubsection{Increasing reuse and recycling by $70 \%$}

Even though site waste management plans have not been utilised widely in the UK, they can be very effective and so they were used in this project to measure reuse, recycling and disposal tonnages.

- Segregation of metal, wood, plasterboard, plastic, paper, cardboard, bricks and glass for reuse or recycling. These materials could then be supplied back through the network for incorporation into products supplied to site.

- Specification of materials with recycled content, low resource impact materials and products.

- Supplying unused materials ordered to site to reuse networks and sourcing reclaimed products (bricks and wood) for use on site.

Working with suppliers to implement reverse logistics.

\begin{tabular}{ll}
\hline Location & Swaythling, Southampton, UK \\
Classification & 13 Residential flats over three floors \\
Client & Talisman Homes \\
Project type & Design and build \\
Construction type & Load-bearing masonary \\
Cost & $\mathrm{f} 860000$ \\
Floor area: $\mathrm{m}^{2}$ & 840 \\
Total site area: $\mathrm{m}^{2}$ & 800 \\
Project duration & September 2012 to June 2013
\end{tabular}

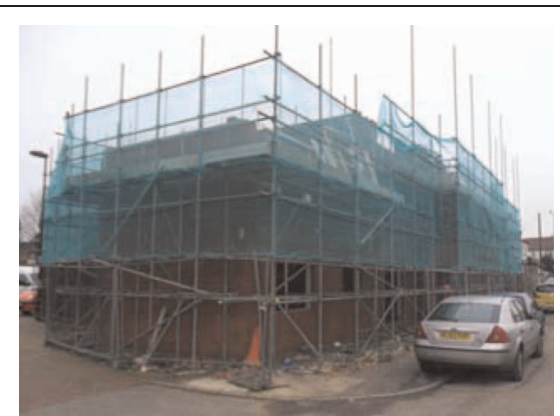

Table 3. Phase 3 (improvement 2): Swaythling, Southampton, UK: site details 
Implementing 80-20 ordering systems and delivering materials just-in-time to site.

\subsubsection{Reducing fresh water use by $75 \%$}

identifying local industries to provide waste or grey water for use on site

using water-efficient machinery (e.g. for mortar mixing)

use of on-site accommodation that incorporates water-saving devices

- identifying materials and options for off-site manufacture.

In order to build an effective network, each of these materials and activities was assessed to measure the effect it could have on site to meet the improvement targets of the project. This analysis identified which activities might have a significant $(>30 \%)$, moderate $(10-30 \%)$ or minor $(<10 \%)$ effect in terms of reduction potential on the phase 2 and 3 sites compared to the baseline. Activities that had significant potential effects were researched further to identify the feasibility of their implementation and to determine if there were industries, companies and organisations that could bring expertise into the industrial network.

The key material streams were identified and agreed from the material types specified during phase 1 . These were product types or parts of the building that were anticipated to be consistent across all three construction phases. These materials were identified as: concrete pad and strip foundations; reinforced concrete frame, in situ slabs and roof; aggregate (fill material); reinforcing rods; brickwork/cladding; blockwork; metal stud partitions internally, insulation and plasterboard; insulation; and carpentry/joinery works. An assessment of how the embodied carbon dioxide of each material could be reduced, by replacing traditional products with sustainable alternatives, was undertaken using The Green Guide (see www. bre.co.uk/greenguide) and the Inventory of Carbon and Energy (see www.bath.ac.uk/mech-eng/research/sert/). Suppliers of sustainable alternatives were then identified and a cost analysis undertaken to determine whether the substitution was viable.

Segregating waste materials at source reduces the amount of contamination, resulting in cleaner materials and significantly improved opportunities for high-level recycling and reuse. When waste materials are commingled on site, they must then be mechanically separated, usually resulting in downcycling or disposal by way of landfill. The intention of creating the industrial network was to develop clean separation of the different residual fractions by developing workforce skills, segregation practices on site, supporting collection and treatment infrastructures, and developing markets for reusable and recycled materials. A SWMP was produced for each case study phase to plan segregation activities and monitor whether recycling targets were being met.

Off-site manufacture is defined as the manufacture of structures built at a different place than the location of their use and occurs at a manufacturing plant specifically designed for a specialised type of process. Individual modules of a building are constructed in a factory, then transported to site, where they are incorporated into the building process. The principal benefits from using off-site manufacture are likely to be improved predictability resulting from more reliable calloff of products and components, shorter lead times, improved product reliability, improved quality, increased resource efficiency, improvements to systems/processes, lower costs, increased social benefits (safer and healthier working environment) and potentially other environmental benefits. There are a number of different types of off-site manufacture that can be incorporated into a construction project. These include preassembled components (e.g. windows, cladding panels, ductwork, trusses) and sub-assemblies. In each phase, areas where off-site manufacture could be undertaken were identifed.

It was anticipated that at least one of the improvement sites would have an existing building that would need to be removed prior to starting construction and this opportunity arose during phase 2 . The opportunity to recycle or reuse materials generated from demolition was regarded as significant for improving reuse and recycling rates on site. Deconstruction was undertaken in a selective and methodical way. A predemolition audit, which involved the quantification of all materials due for demolition and was carried out after the property due for demolition had been vacated, was undertaken during phase 2. The audit classified all materials into reclaimable (reusable), recyclable, hazardous and only suitable for landfill.

Local sources of waste or grey water were identified, which could potentially be supplied to site, including rainwater and waste water from hand basins and so on. A survey was undertaken that successfully identified industries and companies that could potentially provide sources of waste water.

Negotiating reverse logistics with suppliers on a small construction site is difficult as the materials used on site are usually in small quantities and not of sufficient bulk to qualify for take-back. To create the required economies of scale, a consortium of four construction companies was developed to negotiate improved ordering and delivery terms for materials and products. This allowed the negotiation of take-back schemes and 80-20 ordering with key materials suppliers. 


\subsection{Data collection}

Data collection forms were created to log input and output materials used. The following information was collected on phases $1-3$ by metering, on-site or contractor surveying.

\subsubsection{Input data}

types of resources - materials and components - used (i.e. structural framework, secondary aggregate, reinforcement rods, blockwork, brickwork, external framework, insulation, windows, plasterboard)

materials used $(\mathrm{t})$

fresh water use $\left(\mathrm{m}^{3}\right)$

diesel use (1)

electricity use $(\mathrm{kWh})$

- cost of material $(€)$

revenues generated $(€)$

quality of material (individually specified)

distances travelled to site $(\mathrm{km})$.

\subsubsection{Output data}

types of materials generated (i.e. brick, block, concrete, timber, hardcore, mixed waste, glass, plastic and metals)

quantities generated $(\mathrm{t})$

destination of the materials (disposal, reuse or recycling outlet)

cost of disposal or purchase $(€)$

revenues generated $(€)$

quality of material (clean, segregated, suitable for reuse, recycling or disposal)

distances travelled for disposal $(\mathrm{km})$.

Skips of waste material were monitored on site to identify the main waste streams and their chosen disposal route. The disposal route data were provided by the waste management contractor, who provided the tonnage of each material generated and the chosen end destination/disposal route for the output material. The disposal route for each material stream was classified as either reused on site, reused off site, recycled on site, recycled off site, sent to inert waste landfill, or energy recovery.

\subsection{Evaluation of performance}

Performance against the Zerowin targets will be assessed for the improvement scenarios, compared to the baseline, by calculating the greenhouse gases, fresh water usage and recycling rates for all input and output materials and products.

The evaluation stage of the life-cycle assessment will include

the extent to which the improvements implemented by the industrial network met the targets of the Zerowin project the costs of the material flows associated with the implementation of the industrial network using life-cycle costing

the social impact of the industrial network using social life cycle assessment.

These results will be made available on the project website (www.zerowin.eu) and are intended to be published in the peerreviewed literature in due course.

\section{Results and discussion}

\subsection{Construction work}

Using the methodological approaches previously described, phases 1-3 were successfully constructed. Phase 1 involved the construction of a new youth development centre in Aldershot, Hampshire, without any design input. The client was Step by Step Partnership Limited, a charity in Aldershot who wanted to build accommodation to provide shelter and support to homeless young people aged 16-25. The development saw the demolition of two garage units and the construction of a fourstorey mixed-use development (business and accommodation) consisting of a concrete frame, with brick elevations. The total building cost was $£ 2.3$ million and had a net living area of $1395 \mathrm{~m}^{2}$ on a small site of $350 \mathrm{~m}^{2}$, in central Aldershot.

The site was constructed using the following techniques and materials

concrete pad and strip foundations

ground floor in situ reinforced concrete slab

reinforced concrete frame, in situ slabs and roof

Metsec frame inner leaf (a framed steel stud structure, which is fixed between the main frame members and provides a carrier for insulation cladding and plasterboard)

- brickwork/cladding external leaf

angle-ply membrane roof

- metal stud partitions internally, insulated and plasterboarded

powder-coated aluminium windows (some with Suncool glass to reduce solar gain)

bathroom pods (manufactured off site)

screeded floors

full carpentry and joinery works

- external works including secure car and bike parking.

Phase 2 focused on the construction of a new refectory at Reading School in Berkshire, which involved some input into the specification and procurement of some materials and products. The client was Reading School, who wanted to build a new student refectory, with offices, on the site of an old shed and toilet block. The development included the demolition of a shed and toilet block prior to the construction of a 
load-bearing masonry and timber frame roof building. The total building cost was $£ 1 \cdot 2$ million, with a net floor area of $450 \mathrm{~m}^{2}$ and a site area of $580 \mathrm{~m}^{2}$.

Phase 3 focused on the construction of 13 flats in Swaythling, Southampton, with full control over the design of the building and the specification of materials. There was no demolition activity with this site. The client was Talisman Homes who, together with Wilding Butler, purchased the land to build the flats. The development saw the construction of a three-floor building that contained 13 flats and was constructed using a concrete frame and roof. The total building cost was $£ 860000$, with the a net floor area of $840 \mathrm{~m}^{2}$ and a site area of $800 \mathrm{~m}^{2}$.

\subsection{Quantification of materials}

\subsubsection{Phase 1}

The specification of materials was undertaken by the client's design team, who chose traditional products. Some of the material choices made did have a recycled content, but conversations with the design team showed that they had not made a conscious effort to specify these materials. A breakdown of the main material types incorporated in this building is shown in Table 4, while resource consumption and reuse/ recycling rates are shown in Table 5 .

The concrete used in the baseline scenario was manufactured using $100 \%$ Portland cement. Portland cement is mixed with aggregates and water to bind and toughen the concrete. The manufacture of Portland cement is very energy intensive as its components are quarried, heated (to $1450{ }^{\circ} \mathrm{C}$ ) and ground to generate the product, which adds greatly to its embodied carbon dioxide. The environmental impact of concrete can be reduced by substituting Portland cement with by-products from other industries such as slag (from steel making), fly ash (from power plants) and synthetic gypsum (from desulfurisation). The use of $100 \%$ Portland cement in the baseline scenario identified the opportunity, in phases 2 or 3 of the case study, to specify concrete that could incorporate other industry byproducts, as recycled components, to lower the embodied energy and carbon dioxide used in its manufacture.

Aggregates are the broad category of coarse particulate material used in construction. Primary aggregates are materials extracted directly from the ground from quarries or pits and secondary or recycled aggregates are a by-product of mining, quarrying, or as a by-product of other industrial processes such as demolition. Primary aggregates have a higher environmental impact owing to the energy required to undertake the quarrying process. In the baseline scenario, there was a requirement to bring aggregate to the site to be used as a fill material prior to construction. The aggregate specified was made from recycled crushed concrete sourced from a local recycler. Although importing a recycled aggregate to site was a better environmental option than using a primary aggregate, there are still transportation impacts associated with delivery. The most resource-efficient way to source aggregate is to manufacture it on site, by crushing concrete or bricks generated from demolition of a previous structure. The demolition of a set of garages had been undertaken on the site prior to construction starting, but because there was no storage space on site this material was taken away by the waste contractor and recycled off site. An improvement on the phase 2 and 3 sites could be realised if concrete and brick generated from demolition activities undertaken on site could be reused on site, rather than importing the secondary aggregate from a local supplier.

Steel and steel products were equal to concrete and bricks as the most important construction products used in the baseline scenario. In general, steel can be produced by two different technologies: basic oxygen steelmaking (BOS) and electric arc furnace (EAF). The difference between the two technologies is the content of steel scrap used for the processes, with BOS manufactured steel able to accept 10-20\% steel scrap and EAF able to accept up to $100 \%$ steel scrap. Steel with higher recycled content has lower embodied carbon dioxide and energy associated with its manufacture. The reinforcement steel used in the baseline scenario was manufactured using a mix of BOS and EAF and had a recycled steel content of 58\%. Improving the recycled content further by specifying EAF steel only in phases 2 and 3 was identified as a way to reduce the embodied carbon dioxide and energy of the material.

The use of concrete blocks is very common for load-bearing walls of a building. They were specified to construct the external walls of the baseline scenario building. Concrete blocks are made from cast concrete that includes aggregate, usually primary aggregate, manufactured using quarried sand and fine gravel blocks. However, blocks can include industrial wastes as an aggregate, such as pulverised fuel ash from coalfired power stations. The concrete blocks used in the baseline scenario were manufactured using $100 \%$ natural aggregates, so a potential improvement for phases 2 and 3 was to specify a concrete block that incorporated a recycled aggregate to reduce the embodied energy and carbon.

Bricks are made from natural resources such as clay and production is very energy intensive. Bricks manufactured using a modern production facility that incorporates renewable or self-generated energy can reduce the embodied carbon dioxide and energy. There is also the possibility of manufacturing bricks using industrial waste, as a recycled input, to reduce primary resources like sand. Specifying bricks manufactured using an energy-efficient process and recycled content were both potential improvements for the phase 2 and 3 sites. 
Waste and Resource Management

Volume 167 Issue WR4
Resource efficiency networks in

the construction of new

Williams, Curran, den Boer et al.

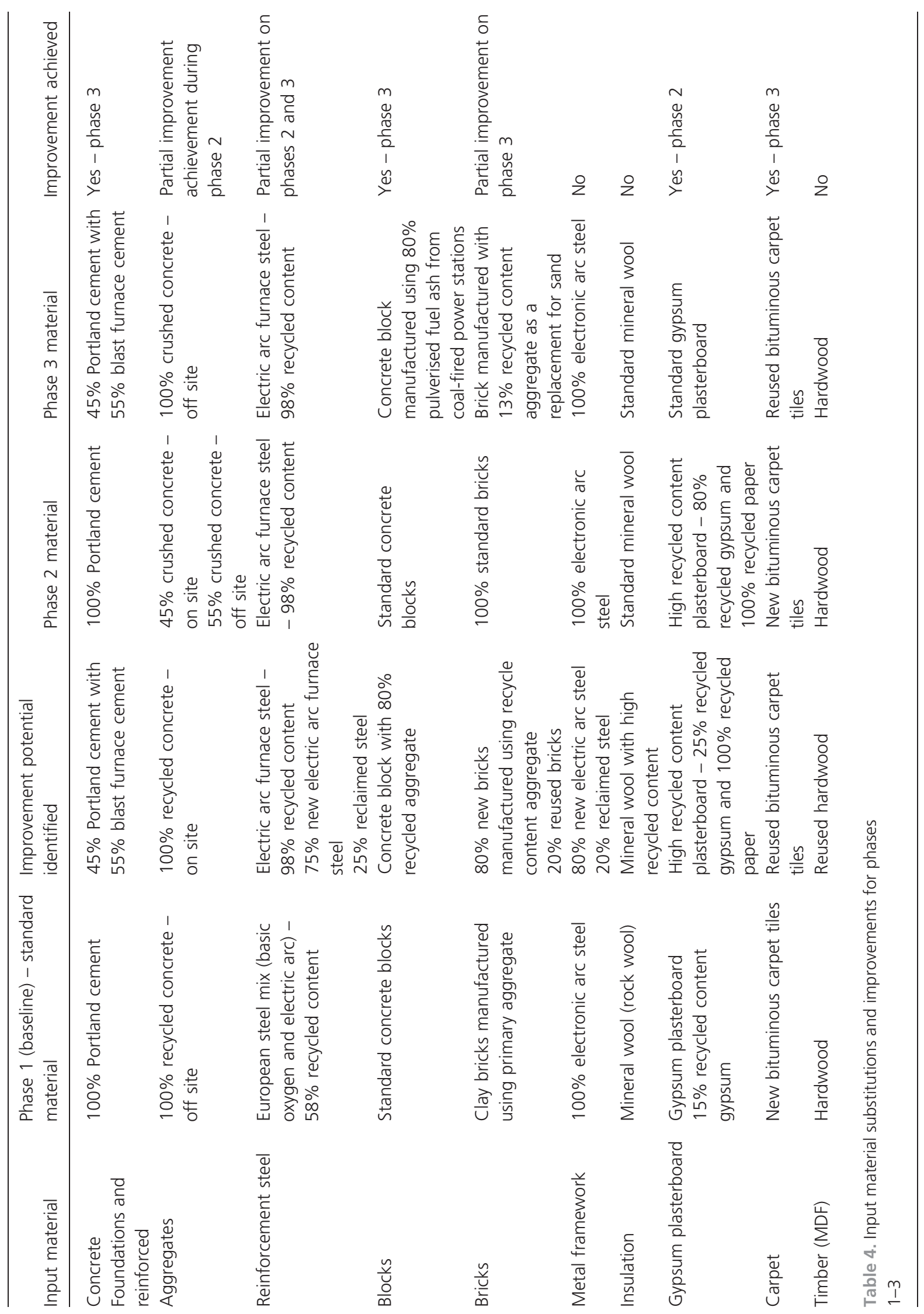




\begin{tabular}{|c|c|c|c|c|}
\hline & \multicolumn{2}{|c|}{ Phase 1} & \multicolumn{2}{|c|}{ Phase 2} \\
\hline \multicolumn{5}{|l|}{ Input resource } \\
\hline Electricity: kWh & \multicolumn{2}{|l|}{368} & \multicolumn{2}{|l|}{119} \\
\hline Fuel/diesel: litres & \multicolumn{2}{|c|}{5045} & \multicolumn{2}{|c|}{50} \\
\hline Water: $\mathrm{m}^{3}$ & \multicolumn{2}{|c|}{$137 \cdot 63$} & \multicolumn{2}{|c|}{$44 \cdot 4$} \\
\hline Disposal method & Tonnage & $\%$ & Tonnage & $\%$ \\
\hline Reuse on-site & 0 & 0 & $20 \cdot 40$ & $21 \cdot 1$ \\
\hline Reuse off-site & 280 & $59 \cdot 3$ & $10 \cdot 04$ & $10 \cdot 4$ \\
\hline Recycling on-site & 0 & 0 & 0 & 0 \\
\hline Recycling off-site & $146 \cdot 06$ & 31 & $60 \cdot 34$ & $62 \cdot 4$ \\
\hline Landfill & $45 \cdot 8$ & $9 \cdot 7$ & $5 \cdot 95$ & $6 \cdot 1$ \\
\hline Total & $471 \cdot 86$ & 100 & $96 \cdot 73$ & 100 \\
\hline
\end{tabular}

Table 5. Resource consumption on site and reuse and recycling rates from phases 1 and 2

The phase 1 building was constructed using a steel frame called Metsec, which is a light gauge, galvanised steel structural framing system. The Metsec frame was used to construct the external framework and internal partitioning of the building. The steel used to manufacture Metsec was produced using EAF technology, which allowed it to be manufactured using $100 \%$ recycled steel. The only way this could be improved in the future phases was to try to incorporate reclaimed steel into the improvement phases.

Insulation in buildings is used for thermal purposes, but insulation also performs other functions such as imparting acoustic or fire retarding properties and impact resistance (e.g. for vibrations caused by industrial applications). There are many types of insulation that are manufactured using many types of materials. Insulation is mainly specified owing to its $\mathrm{U}$-value performance, its ability to retain heat and reduce heat loss. Each material type has different embodied carbon dioxide or energy depending on the materials and energy used in its manufacture. A mineral wool insulation product was specified in the baseline scenario, which compared to all other types of insulation products performs favourably against glass wool, flax, cement and polystyrene urethane foam. As a material, rock wool has the potential to incorporate recycled materials from other industrial processes, including waste post and preconsumer rock wool. This area of further improvement was identified for phases 2 and 3.

Plasterboard products are made from gypsum and fibre to produce a panel made of gypsum plaster pressed between two thick sheets of paper. It is used to make interior walls and ceilings. Gypsum taken for the production of gypsum fibreboards derives from primary production or as a by-product of flue gas desulfurisation called FGD-gypsum. There is a voluntary agreement in the UK with the main manufacturers of plasterboard to offer a take-back scheme to reduce the amount of gypsum that ends up in landfill - the Ashdown agreement on plasterboard recycling. This has resulted in the average post-consumer recycled content of the gypsum in plasterboard increasing to $15 \%$. However, there are plasterboard products available that incorporate $25 \%$ recycled content gypsum as well as recycled paper.

All the main materials and products specified in the phase 1 baseline scenario were manufactured as new products. The carbon dioxide, energy and water use associated with manufacturing these products is high due to the mining, processing, packaging and transportation processes required. A way to reduce these impacts is to specify reclaimed materials that have been generated from demolition or salvage projects. Reclaimed (or reused) products and materials are those that have been taken from the waste stream and reused in their original form with minimal reprocessing, for example steel beams and whole bricks. Substitution of a few well-chosen, locally sourced, reclaimed materials can reduce the environmental impact and the embodied carbon dioxide of a project significantly. These substitutions can sometimes be achieved with little or no additional expense; making use of reclaimed materials is an extremely cost-effective way of cutting carbon dioxide emissions. The main reclaimed materials that could potentially be incorporated into the phase 2 and 3 sites were identified as steel (within an internal frame, or structural steel, if necessary), bricks, carpet and timber.

The output (waste) materials generated from the baseline scenario are detailed in Table 6. The majority of waste was not segregated for recycling, mainly owing to restrictions regarding waste storage, as there was only room on site for one skip to be placed. This meant that materials collected for recycling were mixed (all placed in one skip) and sent to a materials recycling facility (MRF). The mixing of waste creates a contaminated waste stream, which reduces the reuse and recycling potential and end-use opportunities for each material stream.

The concrete generated from the demolition of the garages was segregated on site and transported to a local waste management facility, where it was crushed to produce an aggregate fill and supplied to a local construction site. The material generated from the garages was not suitable for reclamation, so using it to manufacture aggregate was the best option. The only way the disposal could have been improved would have been to reuse it on site, but the quantity produced ( $280 \mathrm{t}$ ) was more than was needed (109 t) and there was no space to store the concrete on or near the site.

The only other material that was segregated on site was waste plasterboard. As part of the Ashdown agreement to recycle plasterboard, the majority of construction sites segregate waste 


\begin{tabular}{|c|c|c|c|c|}
\hline \multirow{2}{*}{ Material } & \multicolumn{2}{|l|}{ Phase 1} & \multicolumn{2}{|l|}{ Phase 2} \\
\hline & Destination & Tonnage & Destination & Tonnage \\
\hline Concrete (demolition) & $\begin{array}{l}100 \% \text { recycled off site to } \\
\text { produce aggregate }\end{array}$ & $280 \cdot 00$ & $\begin{array}{l}100 \% \text { recycled on site to } \\
\text { produce aggregate }\end{array}$ & 20 \\
\hline $\begin{array}{l}\text { Bricks and concrete blocks } \\
\text { (construction) }\end{array}$ & $\begin{array}{l}95 \% \text { recycled off site to } \\
\text { produce aggregate }\end{array}$ & $25 \cdot 48$ & $100 \%$ reused off site & $10 \cdot 04$ \\
\hline Part of a mixed waste skip & $5 \%$ sent to landfill & & & \\
\hline Paper and cardboard (packaging) & $60 \%$ recycled off site & $16 \cdot 82$ & $15 \%$ segregated for reuse & 4 \\
\hline Part of a mixed waste skip & $40 \%$ sent to landfill & & $\begin{array}{l}\text { on site } \\
85 \% \text { recycled off site }\end{array}$ & \\
\hline Timber (construction) & $57 \%$ recycled off site & $25 \cdot 78$ & $94 \%$ recycled off site & $9 \cdot 98$ \\
\hline Part of a mixed waste skip & $43 \%$ sent to landfill & & $6 \%$ sent to landfill & \\
\hline Plastics (packaging) & $31.6 \%$ recycled off site & $24 \cdot 20$ & $90 \%$ recycled off site & $10 \cdot 63$ \\
\hline Part of a mixed waste skip & $\begin{array}{l}1 \cdot 3 \% \text { sent for energy recovery } \\
67 \cdot 1 \% \text { sent to landfill }\end{array}$ & & $10 \%$ sent to landfill & \\
\hline Mixed metals & 95\% recycled off site & $4 \cdot 62$ & $31.6 \%$ recycled off site & 5 \\
\hline Part of a mixed waste skip & $5 \%$ sent to landfill & & $\begin{array}{l}1 \cdot 4 \% \text { sent for energy recovery } \\
67 \% \text { sent to landfill }\end{array}$ & \\
\hline $\begin{array}{l}\text { Plasterboard } \\
\text { Segregated on site }\end{array}$ & $100 \%$ recycled off site & $26 \cdot 70$ & $\begin{array}{l}100 \% \text { recycled off site } \\
0 \% \text { sent to landfill }\end{array}$ & $10 \cdot 58$ \\
\hline $\begin{array}{l}\text { Other mixed construction wastes } \\
\text { including: insulation, textiles and carpets, } \\
\text { general canteen waste, ceramics, inert } \\
\text { materials, plaster and cement }\end{array}$ & $\begin{array}{l}80 \% \text { recycled off site } \\
20 \% \text { sent to landfill }\end{array}$ & $68 \cdot 26$ & $100 \%$ recycled off site & $4 \cdot 2$ \\
\hline Totals & $\begin{array}{l}90 \% \text { reuse/recycling rate } \\
10 \% \text { sent to landfill }\end{array}$ & $471 \cdot 86$ & $\begin{array}{l}93 \% \text { reuse/recycling rate } \\
7 \% \text { sent to landfill }\end{array}$ & $22 \cdot 20$ \\
\hline
\end{tabular}

Table 6. Output materials generated from phases 1 and 2

plasterboard from all other material streams. This practice was undertaken on the baseline scenario, where the plasterboard was sent to a manufacturer for incorporation into new plasterboard products.

The remaining waste streams were placed in 6-m skips on site and sent to a local MRF for sorting. In total, 50 skips were collected from the site between June 2010 and May 2011, containing $165 \mathrm{t}$ of material (excluding concrete generated from demolition and plasterboard). The contractor reported an overall recycling rate for the mixed waste skips of $80 \%$, with $20 \%$ being sent to landfill. The industrial network for phase 1 (baseline) is mapped in Figure 1.

\subsubsection{Phase 2}

Influence over design was limited during phase 2 as it was a build-only project. However, small improvements were implemented; for example, a carbon-dioxide-neutral plasterboard product (Knauf Futurepanel) was used to create the partitions rather than using blockwork. This also resulted in reduced water usage on site because no cement needed to be mixed. The client agreed to two material substitutions. All steel reinforcement bars would be EAF-produced and contain 98\% recycled content steel and, in addition, a sustainable plasterboard product (manufactured using 80\% recycled content gypsum, $100 \%$ recycled content paper and 100\% renewable energy sources) was specified as partitioning for meeting rooms.

Wilding Butler had full control over the waste (output) materials generated on the phase 2 site. Consequently, a pre-demolition audit was undertaken prior to the demolition of an existing toilet block. This highlighted high-value items that were suitable for reuse either on site or through reclamation outlets off site. Several architectural items such as coal-hole covers and timber doors were reclaimed by the school for later reuse on site. The brick walls and concrete were demolished and crushed on site to produce an aggregate fill material used in the construction of a refectory. A metal steel roof frame was sent for scrap. The demolition contractor reused steel posts, structural steel, ceramic toilets, urinals and wash basins. As a result, the only waste materials sent to landfill from the demolition were small plastic items like guttering and soap dispensers. 


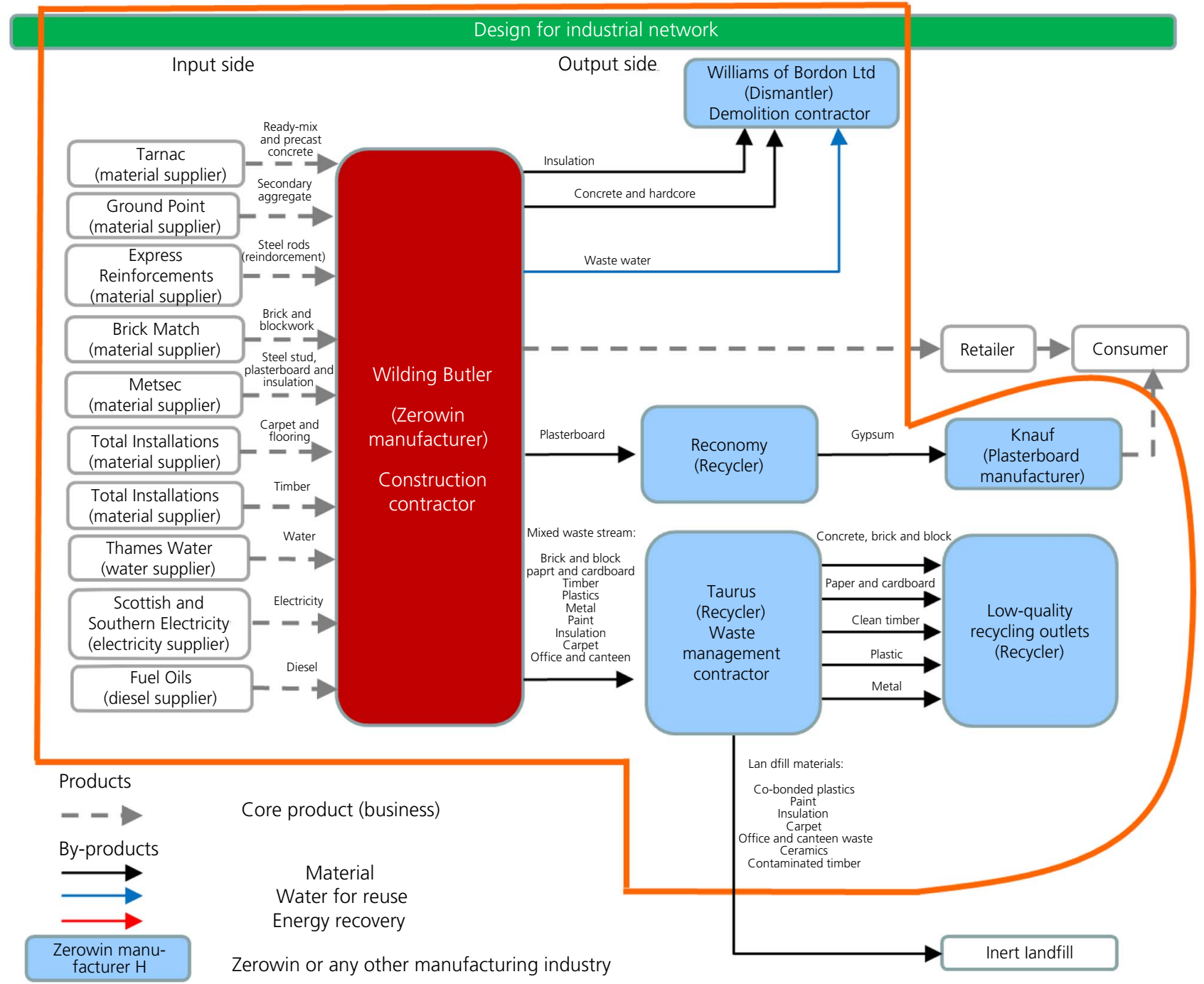

Figure 1. Schematic diagram of industrial network for phase 1

A SWMP was produced that estimated the types and quantities of waste that were going to be generated and how they were to be dealt with. Four main material streams were segregated on site for reuse and recycling: concrete and brick; plasterboard; metal; and timber. The waste concrete and brick was taken by the waste management contractor to manufacture an aggregated product off site. Plasterboard was processed off site to separate the gypsum, paper and metals. The gypsum was sent to manufacture new plasterboard, the paper for reincorporation into paper products and the metals were sent for recycling. The timber was sent to a panel board manufacturer. Space on site was restricted, which meant that more material streams could not be segregated.

Wilding Butler has a policy of ordering 5\% more bricks than needed to site to make sure that sufficient bricks are available if some are broken or damaged. This policy resulted in 190 $(600 \mathrm{~kg})$ bricks being left over after the outer skin was constructed. These bricks were segregated for reuse on site for future maintenance work by Reading School. Analysis of the disposal routes and reuse/recycling for each material stream is given in Tables 5 and 6 .

\subsubsection{Phase 3}

Phase 3 presented new opportunities as Wilding Butler was responsible for the design and build of the flats. Design changes were limited as the plans for the building were approved in 2009 , so significant changes to the design were not permitted, but they were able to focus on material specification. This provided an opportunity to specify sustainable materials that incorporated recycled materials, which would also reduce fresh water consumption and greenhouse gas emissions. 
Waste and Resource Management Volume 167 Issue WR4
Resource efficiency networks in

the construction of new

buildings

Williams, Curran, den Boer et al.
The improved industrial network implemented in phases 2 and 3 is shown in Figure 2. The network sought to link the output material fully with the highest impact and improvement potential with the manufacturers and suppliers of the input material to close the recycling loop and reincorporate the waste streams back into new construction materials. The input materials improvements compared to the baseline are summarised in Table 4.

\subsection{Toxicity of materials}

The issue of toxicity is important to consider when discussing moving to a circular flow of construction materials. Keeping materials with toxic content in use by way of a closed loop can defer dealing with the problem to future users, with possible negative environmental impacts. The Scottish Ecological Design Association commissioned a useful guide to the issues of chemical use in buildings and how to minimise chemical loads in favour of benign construction techniques and material specifications (Liddell et al., 2008).
Eco-design, including green chemistry principles and the reduction of toxic dispersion, was included in the Zerowin approach as one of the key broad approaches to be adopted to move towards sustainable industrial development (Curran and Williams, 2010). Toxicity in building construction was not the focus of the cases presented in this paper, because the aim of the research was to measure the effect of developing an industrial network around construction projects in reducing waste and resource consumption. Human toxicity potential was one of the impact categories in the life-cycle assessment of some of the Zerowin project's studies, such as the effect of producing secondary aggregates to substitute the use of primary materials, and using lightweight concrete blocks with $80 \%$ recycled content (fuel ash) in place of conventional cement. These will be reported on separately.

\section{Conclusion and recommendations}

This case study focused on the development of different industrial networks relating to active construction projects in

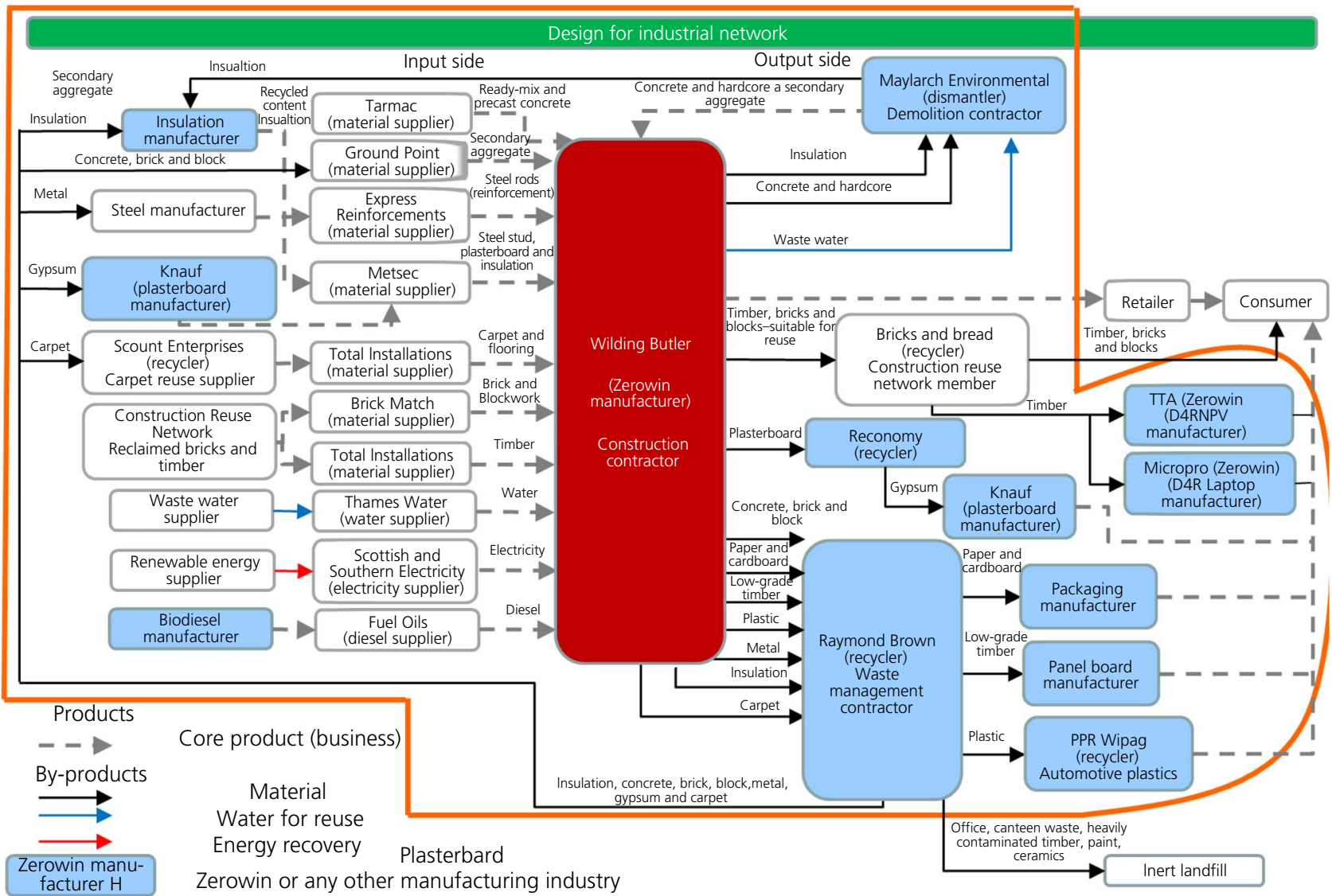

Figure 2. Schematic diagram of improved industrial network for phases 2 and 3 
order to stimulate the creation and implementation of a resource efficiency stakeholder network in the UK. Improvements in resource use were sought by gathering baseline data in the early stages of the case study and working towards increased resource efficiency savings over three progressive phases through the implemented industrial network. Improvements were monitored by recording current usage data in phase 1 , improvements to reuse and recycling in phase 2 , and increasing sustainable procurement of goods and services to reduce resource use in phase 3 (design and build project).

Improvements in phases 2 and 3 were achieved through

increased specification and use of sustainably produced construction materials

- greater separation of materials for recycling (e.g. concrete, brick, metal, wood and plasterboard)

- increased reuse of materials (e.g. concrete and brickwork)

behaviour changes in energy and water use as a result of on-site monitoring.

Restrictions to expanding the industrial network existed where contractual agreements for procurement were decided by the client in advance of the start of the building process, making it difficult to influence the specification for the materials, transport, energy supply and water supply. In these instances a gap between the conceptual model and the implemented model existed. However, in some areas the implemented industrial network was able to improve on the conceptual model by adding value in other areas of sustainability. For example, off-site manufacture of building units reduced transportation and minimised wet trade costs over and above the expectations of the conceptual model.

The industrial network could be further improved and expanded if it were to include the resource use/recovery of other industries and identify industrial symbiosis opportunities. Future research projects in this field could undertake work with localised industries and companies that can be incorporated into the network. Early work shows that sectors such as reclamation, salvage and waste companies, as well as utility companies, could be included in future industrial networks in conjunction with construction companies to achieve even more significant environmental benefits than already achieved through the Zerowin project.

A major barrier to the re-use and recycling of construction and demolition waste is that waste streams tend to be mixed together when there is limited space available on site or when small quantities are produced. Commingled waste streams result in contamination and low-value end markets. However, many construction waste materials are recyclable or can be reused through separation schemes that can increase their residual value and reduce waste collection costs.

Traditionally, the construction sector has been very conservative, risk averse and reluctant to adopt new technologies and ideas. The industry retains a tendency to resort to tried and tested methods of construction rather than using innovative technologies and practices, to reduce the risk of negligence. Construction companies are often reluctant to purchase reused or recycled products unless they have been accredited through recognised EU quality standards. In some cases, companies can use secondary resources where they are 'fit for purpose' in preference to the selection of high-specification new materials. The development of reuse networks for construction materials is at a developmental stage in the UK and there is a real need to support the network to identify sources and end uses for materials.

In some instances the higher cost of sustainable alternative materials and products has proved to be an inhibiting factor in their specification. The most sustainable option is not always cost effective to specify and procure. New innovative products or construction techniques can be more expensive than mainstream traditional practices. The economic climate is forcing clients to focus on cost reductions, which can make it more difficult to influence the use of more sustainable alternatives.

\section{Acknowledgements}

The research leading to these results has received funding from the European Union's Seventh Programme for Research, Technological Development and Demonstration under grant agreement no. 226752.

\section{REFERENCES}

Curran T and Williams ID (2012) A zero waste vision for industrial networks in Europe. Journal of Hazardous Materials 207-208: 3-7.

Defra (Department for Environment, Food and Rural Affairs) (2009) Waste Strategy: Annual Progress Report 2008/09. Defra, London, UK.

Ferguson J, Kermode N, Nash CL, Sketch WAJ and Huxford RP (1995) Managing and Minimising Construction Waste: A Practical Guide. Institution of Civil Engineers, London, $\mathrm{UK}$.

Hobbs G (2008) Construction Resources and Waste Roadmap 2008. Defra, London, UK.

Horta IM, Camanho AS and Moreira da Costa J (2012) Performance assessment of construction companies: A study of factors promoting financial soundness and innovation in the industry. International Journal of Production Economics 137(1): 84-93.

Liddell H, Gilbert J and Halliday S (2008) Design and Detailing for Toxic Chemical Reduction in Buildings. Scottish Ecological 
Design Association (SEDA), Scotland, SEDA Design Guides for Scotland, No. 3. See http://seda.uk.net/assets/ files/guides/dfcrb.pdf (accessed 20/03/2014).

Passivhaus Trust (2012) Projects: Plummerswood. See http:// www.passivhaustrust.org.uk/projects/detail/?cId $=31 \#$. UzrRmvldV8G (accessed 01/04/2014).

SC-Arch (2002) Glencoe Visitor Centre - Gaia Architects. See http://www.sc-arch.co.uk/dfr/Glencoe\%20Visitor\%20 Centre.htm (accessed 01/04/2014).

SFC (Strategic Forum for Construction) (2011) Waste: An Action Plan for Halving Construction, Demolition and Excavation Waste to Landfill. SFC, London, UK, Report 010. See http://www.strategicforum.org.uk/pdf/10WasteActionPlan. pdf (accessed 19/09/2013).

UBM (2014) Optimism Returns to Green Construction as Policy is made at Ecobuild. UBM, London, UK, News Release. See www.ecobuild.co.uk/press/Optimism-returns-to-green-
construction-as-policy-is-made-at-Ecobuild (accessed 01/04/ 2014).

Williams I and Curran T (2010) Literature Review 'Approaches to Zero Waste'. Zerowin deliverable 1.1, dated May 2010. See http://www.zerowin.eu (accessed 31/03/2014).

Williams ID and Turner D (2011) Waste management practices in the small-scale construction industry. In Proceedings of the 13th International Waste Management and Landfill Symposium, S. Margherita di Pula, Cagliari, Sardinia (Cossu R, He P, Kjeldse P et al. (eds)). Cisa Publisher, Padova, Italy, paper no. 003.

WRAP (Waste Resources Action Programme) (2014) Designing for Deconstruction and Flexibility Case Study: Glencoe Visitor Centre, Inveriggan. WRAP, Banbury, Oxfordshire, UK. See http://www.wrap.org.uk/content/designingdeconstruction-and-flexibility-case-study-glencoe-visitorcentre-inveriggan-0 (accessed 01/04/2014).

\section{WHAT DO YOU THINK?}

To discuss this paper, please email up to 500 words to the editor at journals@ice.org.uk. Your contribution will be forwarded to the author(s) for a reply and, if considered appropriate by the editorial panel, will be published as discussion in a future issue of the journal.

Proceedings journals rely entirely on contributions sent in by civil engineering professionals, academics and students. Papers should be 2000-5000 words long (briefing papers should be 1000-2000 words long), with adequate illustrations and references. You can submit your paper online via www.icevirtuallibrary.com/content/journals, where you will also find detailed author guidelines. 